\title{
Gambaran kadar bilirubin pasien tuberkulosis paru selama pengobatan di RSUP Prof. Dr. R. D. Kandou Manado periode Januari 2012 - Desember 2014
}

\author{
${ }^{1}$ Livinia G. Pontoh \\ ${ }^{2}$ Efata B.I. Polii \\ ${ }^{2}$ Fandy Gosal
}

\author{
${ }^{1}$ Kandidat Skripsi Fakultas Kedokteran Universitas Sam Ratulangi Manado \\ ${ }^{2}$ Bagian Ilmu Penyakit Dalam Fakultas Kedokteran Universitas Sam Ratulangi Manado \\ Email: Livinia_tvxq@hotmail.com
}

\begin{abstract}
Indonesia still ranks as the third country in the world to have the most cases of tuberculosis (TB). For this reason, there is a needed treatment for TB, called the Anti-Tuberculosis Drugs (ATD) which comprises of isoniazid, ethambutol, pyrazinamide, rifampicin and streptomycin and this should be taken for 6-8 months. However, ATD has side effects mainly in disturbing the liver function that can be assessed by the serum levels checkup of SGOT, SGPT and bilirubin. This study aimed to determine the level of bilirubin pulmonary TB of patients during the treatment in RSUP Prof. DR. R.D. Kandou Manado for the period of January 2012 to December 2014. This was an observational descriptive study with a cross sectional design by using the medical records of patients of pulmonary TB hospitalization for the period of January 2012 to December 2014. There were 32 patients as samples. There has been an increase in total bilirubin levels during the ATD treatment. It has been discovered that as big as (47\%) had an increase level of total bilirubin. The total of bilirubin levels had increased more in male patients. The increase in the total bilirubin occurred in the age of $>35$ and the more it increases with age. Meanwhile, the increase in direct bilirubin levels had been found in as many as (56\%). The indirect bilirubin levels had been found to be normal in (91\%). A total of (31\%), with hyperbilirubinemia, had not had comorbidities and most had often occurred in the first month of ATD treatment.
\end{abstract}

Keywords: pulmonary tuberculosis, bilirubin, antituberculosis drug, hepatotoxicity

\begin{abstract}
Abstrak: Indonesia masih menempati urutan ketiga negara penderita tuberkulosis (TB) terbanyak didunia. Untuk itulah, dibutuhkan pengobatan TB, yang dinamakan Obat Anti Tuberkulosis (OAT) yang terdiri isoniazid, etambutol, pirazinamid, rifampicin dan streptomisin yang harus dikonsumsi selama 6-8 bulan. Akan tetapi, OAT memiliki efek samping terutama menggangu fungsi hati yang dapat dinilai melalui pemeriksaan kadar serum SGOT, SGPT dan bilirubin. Untuk mengetahui kadar bilirubin pasien TB Paru selama pengobatan di RSUP Prof DR. R.D. Kandou Manado periode Januari 2012-Desember 2014. Desain penelitian yang digunakan adalah penelitian observasional deskriptif dengan pendekatan potong lintang (cross sectional) dengan memanfaatkan rekam medik pasien TB Paru rawat inap periode Januari 2012-Desember 2014. Jumlah sampel yang terpakai sebanyak 32 orang. Terjadi peningkatan kadar bilirubin total selama pengobatan OAT. Ditemukan sebesar (47\%) terjadi peningkatan kadar bilirubin total. Kadar bilirubin total meningkat lebih banyak pada pasien laki-laki. Peningkatan bilirubin total terjadi pada usia >35 tahun dan semakin meningkat seiring bertambahnya usia. Sedangkan, kadar bilirubin direk ditemukan sebanyak (56\%) terjadi peningkatan kadar bilirubin direk. Kadar bilirubin indirek ditemukan normal pada (91\%). Sebanyak (31\%) yang menderita hiperbilirubinemia tidak memiliki penyakit penyerta dan paling sering terjadi pada satu bulan pertama pengobatan OAT.
\end{abstract}

Kata kunci: tuberkulosis paru, bilirubin, obat antituberkulosis, hepatotoksitas 
Tuberkulosis (TB) merupakan penyakit yang disebabkan oleh bakteri Mycobacterium tuberculosis. ${ }^{1}$ TB sendiri, selain dapat menginfeksi Paru tetapi dapat juga menginfeksi organ lainnya. Laporan terakhir dari World Health Organization (WHO) menunjukan hampir 9 juta kasus baru terjadi di tahun 2013 dan 1,5 juta kematian akibat TB. Indonesia merupakan bagian dari Asia Tenggara menempati urutan ke-3 bersamaan dengan Afrika Selatan, sebagai negara dengan insiden TB tertinggi setelah India dan Cina. ${ }^{2}$

Data dari WHO 2011, merilis data jumlah penderita TB di Indonesia diperkirakan prevalensinya 505.614 kasus per tahun dengan 244 per 10.000 penduduk dan 1.550 per hari. Insidennya, 528.063 kasus per tahun dengan rincian 228 kasus per 10.000 penduduk dan 1.447 per hari. Insiden kematian 91.369 per tahun, 30 kasus per 10.000 penduduk dan 250 per hari. ${ }^{3}$ Menurut Riset Kesehatan Dasar (Riskesdas), prevalensi TB Paru tahun 2013 di Provinsi Sulawesi Utara sebesar $0,3 \%$ dari jumlah penduduk yang terdiagnosis TB Paru positif. ${ }^{4}$

Di Indonesia sejak 1994, program pengobatan TB sudah mengacu pada program DOTS. ${ }^{5,6}$ dari: ${ }^{7}$

Prinsip pengobatan TB Paru terdiri

1. Diperlukan dua macam obat yang peka terhadap basil TB, dengan salah satu obat harus bersifat bakterisid.

2. Setelah gejala klinis berangsur baik, dilakukan perpanjangan lama pengobatan untuk mengeliminasi basil yang persisten.

Oleh karena itu, disusun sebuah regimen pengobatan Obat Anti Tuberkulosis (OAT). Lini pertama OAT, terdiri dari obat Isoniazid $(\mathrm{H})$, Etambutol (E), Pirazinamid (Z), Rifampicin (R) dan Streptomisin (S) yang harus diberikan selama 6 bulan, dengan pembagian dosis 2 bulan pertama kombinasi RHZE dan 4 bulan berikutnya kombinasi $\mathrm{RH}^{8}{ }^{8}$

Gangguan fungsi hati merupakan sebuah efek samping akibat penggunaan OAT yang tersering dikeluhkan oleh pasien. $^{9}$ Hal ini, sering disebut Antituberculosis drug induced hepatotoxicity. Ketiga OAT yaitu isoniazid, rifampicin, dan pirazinamid merupakan tiga obat yang dapat menyebabkan hepatotoksitas, karena ketiganya dimetabolisme di hati. Tetapi, kedua OAT yaitu etambutol dan streptomisin tidak menyebabkan hepatotoksik. ${ }^{10}$ Evaluasi fungsi hati dapat dilakukan beberapa pemeriksaan kontrol sebagai mencegah efek samping dari OAT di Indonesia adalah SGOT, SGPT dan bilirubin. $^{7}$

Penelitian ini bertujuan untuk mendapatkan gambaran kadar bilirubin pasien TB Paru selama pengobatan di RSUP Prof DR. R.D. Kandou Manado periode Januari 2012-Desember 2014.

\section{METODE PENELITIAN}

Desain penelitian ini merupakan penelitian observasional deskriptif dengan pendekatan potong lintang (cross sectional), dengan memanfaatkan data sekunder berupa rekam medik di RSUP Prof DR. R.D. Kandou Manado periode Januari 2012- Desember 2014. Subjek penelitian adalah semua rekam medik penderita TB Paru yang melakukan pemeriksaan kadar biliribun setelah menjalani pengobatan TB Paru di bagian/SMF Ilmu Penyakit Dalam RSUP Prof DR. R.D Kandou Manado periode Januari 2012-Desember 2014. Penelitian dilakukan dalam jangka waktu OktoberDesember 2015. Variabel yang digunakan dalam penelitian adalah jenis kelamin, umur, penyakit kormobid, lama pengobatan OAT dan hasil laboratorium kadar bilirubin indirek, direk dan total.

\section{HASIL PENELITIAN \\ Karakteristik Sampel Penelitian}

Sampel penelitian berjumlah 32 data rekam medis pasien penderita TB Paru yang sedang menjalani pengobatan OAT dan melakukan pemeriksaan kadar bilirubin serum dan memenuhi kriteria inklusi. 
Tabel 1. Karakteristik Sampel Penelitian

\begin{tabular}{llllll}
\hline Sampel & $\begin{array}{l}\text { Um } \\
\text { ur }\end{array}$ & JK & $\begin{array}{l}\text { B. } \\
\text { Total }\end{array}$ & $\begin{array}{l}\text { B. } \\
\text { Direk }\end{array}$ & $\begin{array}{l}\text { B. } \\
\text { Indirek }\end{array}$ \\
\hline $\mathrm{N}$ & 32 & $\begin{array}{l}\hat{\delta}=20 \\
\hat{\delta}=12\end{array}$ & 32 & 32 & 32 \\
\hline Min & 25 & & 0.30 & 0.10 & 0.20 \\
\hline Max & 79 & & 13.79 & 10.68 & 3.80 \\
\hline Rerata & 53. & & 2.483 & 1.981 & 0.502 \\
& 03 & & & & \\
\hline Median & 55. & 1.981 & 0.850 & 0.305 \\
& 00 & & & & \\
\hline Simpang & 13. & & 3.032 & 2.638 & 0.670 \\
Baku & 785 & & & & \\
\hline $\begin{array}{l}\text { Distribus } \\
\text { i }\end{array}$ & - & 2.444 & 2.152 & 4.280 \\
& 0.1 & & & \\
\hline
\end{tabular}

Keterangan: $\mathrm{N}=$ jumlah sampel, JK=jenis kelamin, $\mathrm{B}=$ Bilirubin

Usia rata-rata pasien adalah 53,03 tahun dengan usia pasien tertua adalah 79 tahun dan usia termuda adalah 25 tahun. Berdasarkan jenis kelamin terdiri dari 20 laki-laki dan 12 perempuan. Kadar bilirubin total rata-rata $2,483 \mathrm{mg} / \mathrm{dl}$, dengan kadar terendah 0,30 $\mathrm{mg} / \mathrm{dl}$ dan kadar tertinggi 13,79 mg/dl. Kadar bilirubin direk rata-rata 1,981 $\mathrm{mg} / \mathrm{dl}$ dengan kadar terendah 0,10 $\mathrm{mg} / \mathrm{dl}$ dan kadar tertinggi $10,68 \mathrm{mg} / \mathrm{dl}$. Kadar bilirubin indirek ratarata $0,502 \mathrm{mg} / \mathrm{dl}$ dengan kadar terendah $0,20 \mathrm{mg} / \mathrm{dl}$ dan kadar tertinggi 3,80 mg/dl.

\section{Distribusi Pasien TB Paru yang Melakukan Pemeriksaan Kadar Bilirubin}

\section{Bilirubin Total}

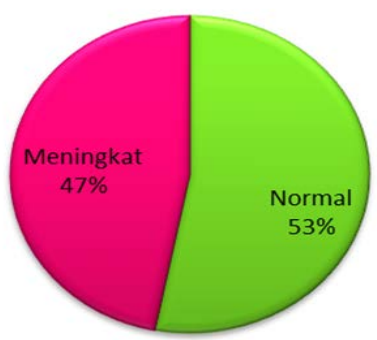

Gambar 1. Distribusi Pasien TB Paru yang Melakukan Pemeriksaan Kadar Bilirubin Total

Distribusi pasien TB paru yang melakukan pemeriksaan kadar bilirubin total selama pengobatan, didapatkan kadar bilirubin total normal pada 17 pasien (53\%) dan peningkatan kadar bilirubin total pada 15 pasien $(47 \%)$.

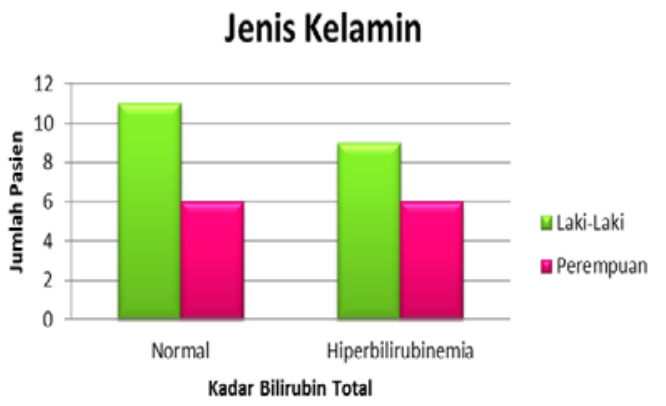

Gambar 2. Distribusi Sampel Berdasarkan Kadar Bilirubin Total dan Jenis Kelamin

Dapat dilihat dari 32 pasien tersebut terdapat 11 pasien (55,0\%) dengan jenis kelamin laki-laki dan hasil kadar bilirubin total normal, 6 pasien (50,0\%) dengan jenis kelamin perempuan dan hasil kadar bilirubin total normal, 9 pasien $(45,0 \%)$ dengan jenis kelamin laki-laki dan hasil kadar bilirubin total yang meningkat, 6 pasien (50,0\%) dengan jenis kelamin perempuan dan hasil kadar bilirubin total meningkat.

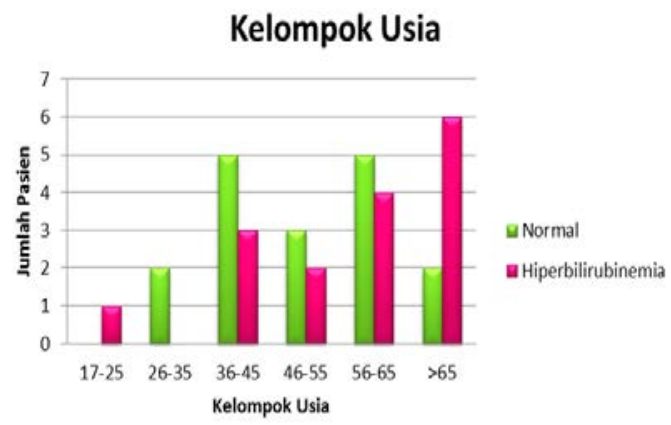

Gambar 3. Distribusi Sampel Berdasarkan Kadar Bilirubin Total dengan Kelompok Usia

Distribusi berdasarkan usia didapatkan peningkatan kadar bilirubin total kelompok usia 17-25 tahun berjumlah 1 (6,7\%) dan kadar bilirubin total normal berjumlah 0 (0\%). Peningkatan kadar bilirubin total kelompok usia 26-35 tahun berjumlah 0 (0\%) dan kadar bilirubin total normal berjumlah 2 (11,8\%). Peningkatan kadar bilirubin total kelompok usia 36-45 tahun 
berjumlah 3 (20,0\%) dan kadar bilirubin total normal berjumlah 5 (29,4\%). Peningkatan kadar bilirubin total kelompok usia 46-55 tahun berjumlah 2 (13,3\%) dan kadar bilirubin total normal berjumlah 3 (17,6\%). Peningkatan kadar bilirubin total kelompok usia 56-65 tahun berjumlah 4 (26,7\%) dan kadar bilirubin total normal berjumlah 5 (29,4\%). Serta peningkatan kadar bilirubin total kelompok usia >65 tahun berjumlah 5 (33,5\%) dan kadar bilirubin total normal berjumlah 2 (11,8\%).

\section{Bilirubin Direk}

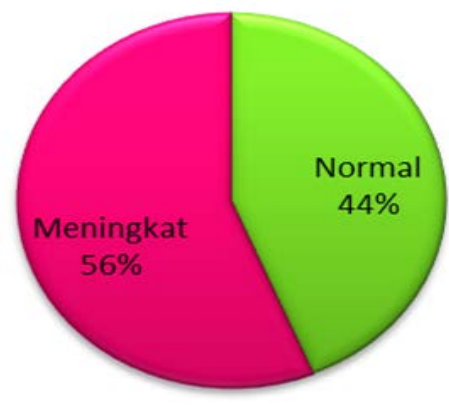

Gambar 4. Distribusi Pasien TB Paru yang Melakukan Pemeriksaan Kadar Bilirubin Direk

Distribusi pasien TB paru yang melakukan pemeriksaan kadar bilirubin direk selama pengobatan, didapatkan kadar bilirubin direk normal pada 14 pasien (44\%) dan peningkatan kadar bilirubin direk pada 18 pasien (56\%). Tetapi, pada 18 pasien yang mengalami peningkatan kadar bilirubin direk, terdapat 3 pasien yang kadar bilirubin total bernilai normal. Hal ini disebabkan karena rendahnya nilai kadar bilirubin indirek dan peningkatan bilirubin direk belum memberikan perubahan terhadap kadar bilirubin total untuk dapat melewati nilai batas atas.

Distribusi pasien TB paru yang melakukan pemeriksaan kadar bilirubin indirek selama pengobatan, didapatkan kadar bilirubin indirek normal pada 29 pasien (91\%) dan peningkatan kadar bilirubin indirek pada 3 pasien (9\%).

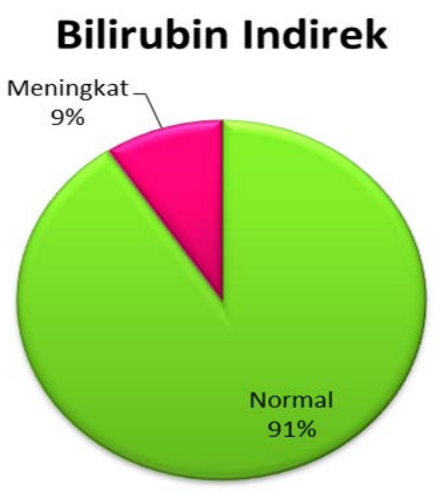

Gambar 5. Distribusi Pasien TB Paru yang Melakukan Pemeriksaan Kadar Bilirubin Indirek.

\section{Distribusi Pasien TB Paru yang Mengalami Hiperbilirubinemia}

\section{Penyakit Penyerta}

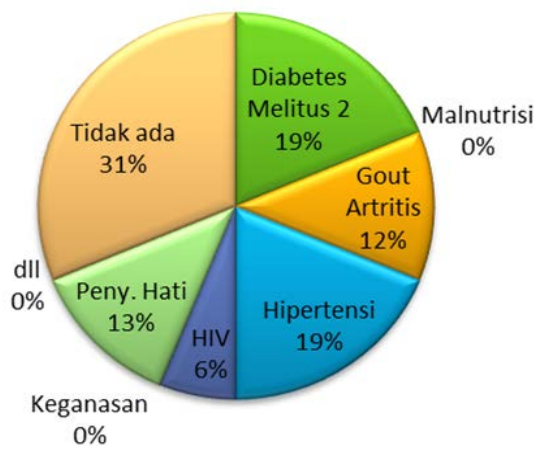

Gambar 6. Penyakit Penyerta dalam Pasien Hiperbilirubinemia pada TB Paru

Pada 15 pasien TB Paru yang mengalami peningkatan kadar bilirubin serum total yang sedang menjalani pengobatan OAT, yang terbanyak adalah tidak ditemukan adanya penyakit penyerta berjumlah 5 pasien (31\%), kemudian disusul oleh penyakit Hipertensi (19\%) dan Diabetes Melitus 2 (19\%) masing-masing berjumlah 3 pasien.

Konsumsi OAT pada fase intensif (bulan ke-1) ditemukan terjadinya peningkatan kadar bilirubin total terutama pada minggu pertama penggunaan OAT sebanyak 6 pasien (40,0\%), minggu kedua sebanyak 1 pasien (6,7\%), minggu ketiga sebanyak 2 pasien $(13,3 \%)$ dan minggu keempat 1 pasien $(6,7 \%)$. 


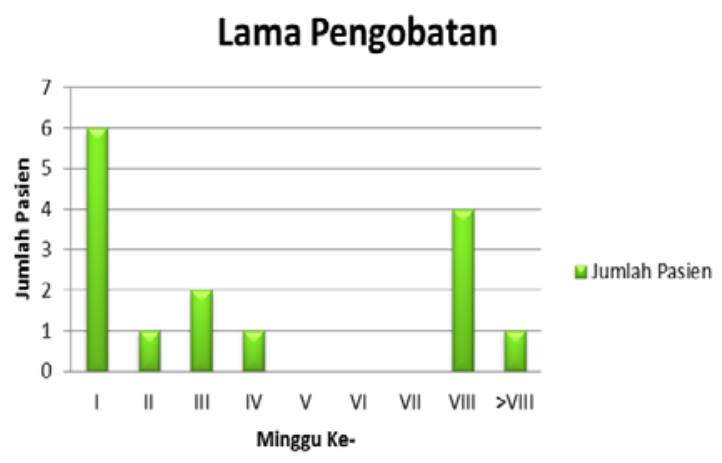

Gambar 7. Distribusi Pasien Hiperbilirubinemia Berdasarkan Lamanya Pengobatan OAT

\section{BAHASAN}

Walaupun terdapat berbagai penuntun penegakkan diagnosis untuk cedera hati imbas obat, tetapi parameter peningkatan kadar bilirubin masih merupakan salah satu kriteria. Salah satunya yaitu American Thoracic Society, menjelaskan bahwa peningkatan kadar bilirubin sebanyak dua kali lipat dari batas atas normal dan sama atau lebih tiga kali lipat konsentrasi alanine aminotransferase (ALT) merupakan salah satu dari tiga kriteria pasien TB Paru menderita cedera hati imbas obat. $^{11}$ Sharma, dkk menggunakan lima kriteria diagnosis cedera hati imbas obat yang salah satunya terjadi peningkatan kadar bilirubin serum total sebesar $>1,5 \mathrm{mg} / \mathrm{dL} .^{12}$

Dalam penelitian ini ditemukan 20 pasien jenis kelamin laki-laki dan 12 pasien jenis kelamin perempuan dengan usia ratarata pasien yang melakukan pemeriksaan bilirubin 53,03 tahun. Hasil penelitian yang dilakukan oleh Naqvi, dkk, memperoleh jumlah sampel yang sama dimana jumlah sampel jenis kelamin laki-laki lebih banyak daripada perempuan, dengan rentang dari sampel kebanyakan berusia $>35$ tahun. $^{11}$ Dari hasil penelitian, rerata kadar bilirubin total, direk dan indirek berturut-turut 2,483 mg/dL, 1,981 mg/dL dan 0,305 mg/dL. Hal ini menggambarkan bahwa rerata kadar bilirubin total dan direk pada pasien meningkat selama mengkonsumsi OAT dengan kadar bilirubin total, direk dan indirek secara normal berturut-turut 0,3-1,3 $\mathrm{mg} / \mathrm{dL}, 0,1-0,4 \mathrm{mg} / \mathrm{dL}$, dan kadar bilirubin indirek dalam rentang normal 0,2-0,9 $\mathrm{mg} / \mathrm{dL} .{ }^{1}$ Hal ini terjadi akibat efek samping dari OAT terutama isoniazid, rifampisin, etionamid dan pirazinamid yaitu menyebabkan hepatotoksitas. ${ }^{1,7}$

Jumlah pasien TB Paru yang kadar bilirubin serum total meningkat sebesar 47\%, ini sejalan dengan penelitian oleh Khadka, dkk bahwa pasien TB Paru yang mengalami peningkatan kadar bilirubin serum total selama pengobatan sebesar 35\%. Selain karena pengobatan OAT, ini terjadi akibat adanya penyakit hati, malnutrisi, konsumsi alkohol, regimen pengobatan dan koinfeksi HIV yang diderita oleh beberapa pasien sebagai sampel. ${ }^{13}$

Berdasarkan jenis kelamin diperoleh perbedaan antara pasien yang mengalami peningkatan kadar bilirubin serum total dimana sebesar 9 pasien laki-laki dan 6 pasien perempuan, mengalami peningkatan kadar bilirubin total. Meskipun dalam penelitian sebelumnya, ditemukan bahwa jenis kelamin perempuan lebih beresiko menderita cedera hati imbas obat. ${ }^{14}$ Alasan diketahui mengapa jenis kelamin perempuan lebih beresiko adalah variasi farmakokinetik dan status acetylator yang lambat. ${ }^{15}$ Laki-laki memiliki kemampuan sebagai faktor protektif hati, ini dikarenakan bahwa peningkatan aktivitas hormon androgen menginduksi aktivitas enzim mikrosomal hepar, yang membuat laki-laki mampu metabolisme obat secara efektif. Akan tetapi, penelitian lebih jauh mengenai variasi jenis kelamin dalam metabolisme obat dibutuhkan untuk menarik kesimpulan yang lebih definitif. ${ }^{16}$ Walaupun dalam beberapa penelitian terbaru yang dilakukan seperti penelitian oleh Naqvi, dkk mendapatkan hasil dimana laki-laki lebih dominan menderita cedera hati imbas obat. ${ }^{11}$

Berdasarkan kelompok umur, semakin bertambahnya usia maka semakin meningkat angka kejadian peningkatan kadar bilirubin total pada pasien dan semakin menurunnya angka kadar bilirubin total normal. Ini dibuktikan dengan teori bahwa semakin tua usia maka semakin 
tinggi risiko menderita cedera hati imbas otak. Ini diakibatkan dengan keadaan orang tua karena terjadi penurunan klirens, interaksi obat-obat, penurunan aliran darah hati, variasi ikatan obat, volume hati yang rendah selain itu diet yang buruk, infeksi sekunder dan pengobatan ulang juga menjadi alasan yang penting. ${ }^{14}$ Angka kejadian hiperbilirubinemia terjadi lebih banyak pada pasien yang berusia $>35$ tahun dalam penelitian ini, sejalan dengan penelitian yang dilakukan oleh Singla, dkk bahwa salah satu faktor risiko dari cedera hati imbas obat. ${ }^{12}$

Kadar bilirubin direk pada pasien TB Paru yang sedang menjalani pengobatan OAT meningkat sebesar 56\%. Penelitian yang dilakukan oleh Wahyuningsih, dkk menemukan sebesar 36,4\% pasien TB Paru mengalami peningkatan kadar bilirubin direk. ${ }^{17}$ Peningkatan kadar bilirubin direk ini disebabkan oleh adanya cedera iskemik pada hati, yang mengakibatkan terganggunya fungsi dari hati yakni memindahkan bilirubin dari dalam plasma ke empedu. ${ }^{18}$

Kadar bilirubin indirek dari penelitian hanya ditemukan sebesar 9\% pasien TB Paru yang mengalami peningkatan kadar bilirubin indirek, walaupun nilai ini cukup kecil dibandingkan dengan penelitian yang pernah dilakukan di RSUP Dr Kariadi Semarang yakni sebesar 26,4\%. ${ }^{17}$ Peningkatan kadar bilirubin indirek hanya terjadi pada kondisi seperti hemolisis, sindrom Gilbert, sindrom Crigler-najjar, inefektif eritropoesis, dan reabsorpsi dari hematoma yang besar. ${ }^{19}$

Kebanyakan pasien TB Paru yang diobati dengan OAT tidak memiliki penyakit penyerta sebesar $31 \%$ yang kemudian diikuti dengan penyakit Diabetes Melitus 2 dan Hipertensi. Hasil dari penelitian sebelumnya yang dilakukan oleh Rifai A, dkk juga menemukan hal yang sama. $^{20}$ Hal ini menandakan bahwa, hepatotoksitas dapat terjadi tanpa adanya penyakit penyerta. Pada penelitian yang dilakukan oleh Xiao, dkk menemukan bahwa Diabetes Melitus 2 merupakan faktor risiko hepatotoksitas karena OAT. ${ }^{21}$
Diabetes memiliki efek negatif dalam pengobatan tuberkulosis, ini berhubungan dengan perubahan farmakokinetik OAT pada pasien diabetes. Selain itu tidak ditemukan adanya perbedaan antara pasien diabetes dan pasien tidak diabetes yang menggunakan OAT fase intensif. ${ }^{22}$ Keadaan seperti malnutrisi, penyakit hati dan HIV merupakan kormobid yang memperburuk keadaan ini. ${ }^{14}$

Lamanya paparan terhadap toksik OAT pada hati mengakibatkan terjadi perubahan pada kadar bilirubin total pasien TB Paru, sebanyak 15 pasien ditemukan mengalami perubahan kadar bilirubin total. Kebanyakan pasien TB mengalami hiperbilirubinemia pada bulan pertama mengkonsumsi OAT. Meskipun pada penelitian sebelumnya oleh Wagan, dkk bahwa peningkatan kadar bilirubin hanya terjadi pada dua dan tiga bulan pertama terapi OAT. ${ }^{23}$ Hal in disebabkan karena pada bulan pertama dan kedua merupakan fase intensif dari pemberian OAT, pemberian empat regimen pengobatan sekaligus selama 2 bulan. Ini diakibatkan terjadinya inhibisi pada sekresi sintesis empedu dan ekskresi dari asam empedu dan bilirubin dan kolesterol dalam empedu. ${ }^{10,23,24}$

\section{SIMPULAN}

1. Penderita TB Paru yang menjalani pengobatan OAT dan melakukan pemeriksaan kadar bilirubin berjumlah 32 pasien, rerata berusia 53,03 tahun, terbagi menjadi 20 laki-laki dan 12 perempuan. Rerata kadar bilirubin total dan direk mengalami peningkatan dari nilai kadar normal sebesar 2,483 mg/dL dan $1,981 \mathrm{mg} / \mathrm{dL}$.

2. Terdapat $47 \%$ pasien dengan kadar bilirubin total meningkat.

3. Jenis kelamin pasien dengan kadar bilirubin meningkat lebih banyak terjadi pada laki-laki dibanding dengan perempuan.

4. Terjadi perbandingan terbalik pada usia pasien TB yang mengkonsumsi OAT, dimana orang muda memiliki kadar bilirubin normal sedangkan orang tua 
mengalami peningkatan.

5. Kadar bilirubin direk meningkat sebesar $56 \%$.

6. Kadar bilirubin indirek normal sebesar 91\%.

7. Kebanyakan pasien TB Paru dengan cedera hati imbas obat tidak memiliki penyakit penyerta.

8. Kadar bilirubin total selama pengobatan OAT meningkat pada satu bulan pertama.

\section{SARAN}

1. Penderita TB Paru sebaiknya melakukan pemeriksaan laboratorium kadar bilirubin setiap 2 minggu selama pengobatan fase intensif TB Paru sebagai evaluasi pengobatan.

2. Diperlukan edukasi dan pengawasan yang ketat terhadap konsumsi OAT selama fase intensif mencegah terjadi kondisi putus obat.

3. Perlu adanya perhatian dalam kelengkapan data dalam rekam medik.

4. Untuk penelitian selanjutnya sebaiknya ditambahkan variabel seperti kadar SGOT, kadar SGPT, indeks massa tubuh, gejala klinis, riwayat konsumsi alkohol dan formula OAT.

\section{DAFTAR PUSTAKA}

1. Wardhani AP, Uyainah A. Tuberkulosis. In: Tanto C, Liwang F, Hanifati S, Pradipta EA, editor. Kapita Selekta Kedokteran. 4th ed. Jakarta Pusat: Media Aesculapius; 2014. h 828-32.

2. World Health Organization. Global tuberkulosis report 2014. Geneva: World Health Organization; 2014.

3. Kementerian Kesehatan. Laporan situasi terkini perkembangan tuberkulosis di Indonesia januari-juni 2011. Jakarta: Ditjen PP dan PL, 2011.

4. Kementerian Kesehatan Republik Indonesia. Riset Kesehatan Dasar Riskesdas 2013. Jakarta: Badan Penelitian dan pengembangan kesehatan, 2013.

5. World Health Organization. What is DOTS? a guide to understanding the WHOrecommended TB control strategy known as DOTS. Geneva: Communicable Diseases Cluster
Prevention and Control World Health Organization,1999.

6. Kementerian Kesehatan Republik Indonesia. Terobosan menuju akses universal strategi nasional pengendalian tb di di Indonesia 2010-2014. Jakarta: Direktorat Jenderal Pengendalian Penyakit dan Penyehatan Lingkungan, 2011.

7. Amin Z, Bahar A. Pengobatan Tuberkulosis Mutakhir. Dalam: Sudoyo AW, Setiyohadi B, Alwi I, Simadibrata M, Setiadi S, editor. Ilmu penyakit dalam. 4th ed. Jakarta Pusat: Interna Publishing; 2009. h 2241-42.

8. Surya A, Basri C, Kusmo S. Dalam: Pedoman Nasional Pengendalian Tuberkulosis. Jakarta: Kementerian Kesehatan Republik Indonesia Jenderal Pengendalian Penyakit Dan Penyehatan Lingkungan. 2011.

9. Gulbay BE, Gurkan OU, Yildiz OA, Onen ZP, Erkekol FO, Baccioglu A, et al. Side effects due to primary antituberculosis drugs during the intial phase of therapy in 1149 hospitalized patients for tuberculosis. Respir Med. 2006 Oct;100(10):183442.

10.Tostmann A. Boeree MJ, Aarnoutse RE, Lange WCM, Ven AJAM, Dekhuijzen R. Antituberculosis drug induced hepatotoxicity: concise up to date review. J Gastroenterol Hepatol. 2008 Feb;23(2):192-202.

11.Naqvi IH, Mahmood K, Talib A, Mahmood A. Antituberculosis drug induced liver injury: an ignored fact, assessment of frequency, patterns, severity and risk factors. OJGas. 2015 5, 173-184.

12.Sharma SK, Singla R, Sarda $P$, Mohan A, Makharia G, Jayaswal A, et al. Safety of 3 different reintroduction regimens of antituberculosis drugs after development of antituberculosis treatment-induced hepatotoxicity. Clin Infect Dis. 2010 Mar 15;50(6):833-9.

13.Khadka J, Malla P, Jha SS, Poudel SR. The study of drug induced hepatotoxicity in att patients attending in national tuberculosis center in bhaktapur. SAARC J. Tuber. Lung Dis. HIV/AIDS. 2009 
VI (2) 17-21.

14. Mehta N, Ozick LA, Gbadehan E. Drug induced hepatotoxicity, New York; [Internet]. 2014 Okt 09 [diakses 23 Sep 2015]. Tersedia: http://emedicine.medscape.com/articl e/169814-overview

15.Makhlouf HA, Helmy A, Fawzy E, ElAttar M, Rashed HAG. A prospective study of antituberculous drug induced hepatotoxicity in an area endemic for liver disease. Hepatol Int. 2008 2:353-360.

16.Resende LSO, Santos-Neto ETD. Risk factor associated with adverse reactions to tuberculosis drugs. J Bras Pneumol. 2015;41(1):77-89.

17.Wahyuningsih E. Pola klinik tuberkulosis paru di rsup dr kariadi semarang periode juli 2012-agustus 2013 [skripsi]. Semarang: Universitas Diponegoro; 2014.

18. Navarro VJ, Senior JR. Drug-related hepatotoxicity. $\mathrm{N}$ Engl J Med 2006;354:731-9. 30.

19.Sulaiman A. Pendekatan klinis pada pasien iketrus. Dalam: Sudoyo AW, Setiyohadi B, Alwi I, Simadibrata M, Setiadi S, editor. Ilmu penyakit dalam. 4th ed. Jakarta Pusat: Interna
Publishing; 2009. p. 635-36.

20.Rifai A, Herlianto B, Mustika S, Pratomo B, Supriono. Gambaran klinis hepatitis akibat obat anti tuberkulosis di rumah sakit umum daerah dr saiful anwar malang. Jurnal Kedokteran Brawijaya. 2015 Feb;28:238-41.

21.Xiao QH, Deng ZZ, Liu JX, et al. Risk factor analysis of hepatic toxicity of antituberculosis agents. Chin J Antibiot. 2004;29:760-1.

22.Atmaca HU, Akbas F, Demir P, Uysal BB, Altinok R, Erdenen F. An antitubercular therapy induced hepatotoxicity case with diffuse ascites. Istanbul Med J. 2013;14:2157.

23.Wagan MA, Shah S, Khokhar GN, Memon AR. A study on hepatic dysfunction during dots therapy for pulmonary tuberculosis. Pakistan Journal of Pharmacology. 2008 July:25(2):7-12.

24. Amin Z, Bahar A. Tuberkulosis paru. Dalam: Sudoyo AW, Setiyohadi B, Alwi I, Simadibrata M, Setiadi S, editor. Ilmu penyakit dalam. 4th ed. Jakarta Pusat: Interna Publishing; 2009. P. 2232-39. 